\title{
FAKTOR-FAKTOR YANG MEMPENGARUHI NILAI AKTIVA BERSIH REKSADANA MANULIFE SYARIAH SEKTOR AMANAH ${ }^{1]}$
}

\author{
Yesika Novita Lintang Gumilang \\ Mahasiswa Program Studi Ekonomi Islam-Fakultas Ekonomi dan Bisnis-Universitas Airlangga \\ Email: yesika.novita-12@feb.unair.ac.id
}

Leo Herlambang

Departemen Ekonomi Syariah-Fakultas Ekonomi dan Bisnis-Universitas Airlangga

Email: leo.herlambang@feb.unair.ac.id

\begin{abstract}
:
Mutual funds can be bridging For Small investors but Want to invest hearts Capital Markets Namely mutual funds, but so far there is hardly any who see mutual funds as part of an attractive investment exceeds savings, deposits, or even stocks. There is factors that affect Net Asset Value namely interest rates and market unsystematic risk. Based on this study proved this study uses a quantitative approach to the study results The results of this study is the Effect of interest rate and market unsystematic risk to Net Asset Valve simultaneously significantly. The influence of interest rates on the second partial Net Asset Value significantly, interest rates affect the Net Asset Value of $99.4 \%$, which means have a strong influence on the NAB. The effect of market unsystematic risk on a third partially NAB insignificant. market unsystematic risk affect the NAB amounted to only 66.2\%.
\end{abstract}

Keywords : Mutual Funds, Net Asset Value, Interest Rates, and market unsystematic risk

\section{PENDAHULUAN}

\section{Latar Belakang}

$\begin{array}{ccc} & \text { Munculnya Reksadana Syariah } \\ \text { pada tahun 1997, mengalami }\end{array}$
pertumbuhan yang terus meningkat dari sisi jumlah penerbitan maupun Nilai Aktiva Bersih terus meningkat, tidak hanya reksadana konvensional tetapi reksadana syariah juga mengalami peningkatan. . Berdasarkan DSN - MUI No 20/DSNMUI/IX/2001 , Reksadana Syari'ah adalah Reksadana yang beroperasi menurut ketentuan dan prinsip Syari'ah Islam, baik dalam bentuk akad antara pemodal sebagai pemilik harta (sahib al-mal/ Rabb al Mal) dengan Manajer Investasi sebagai wakil shahib al-mal, maupun antara Manajer Investasi sebagai wakil shahib almal dengan pengguna investasi. Mudharabâh/qirad adalah suatu akad atau sistem di mana seseorang memberikan hartanya kepada orang lain untuk dikelola dengan ketentuan bahwa keuntungan yang diperoleh (dari hasil pengelolaan tersebut) dibagi antara kedua pihak, sesuai dengan syarat-syarat yang disepakati oleh kedua belah pihak, sedangkan kerugian ditanggung oleh shahib al-mal sepanjang tidak ada kelalaian dari mudharib.

(Ryandono, 2009:69) menjelaskan bahwa:

"Islam memandang semua perbuatan yang dilakukan manusia dalam kehidupan sehari-hari, termasuk aktivitas ekonominya sebagai investasi yang akan mendapatkan hasil (return). Return investasi dalam Islam sesuai dengan besarnya sumber daya yang dikorbankan dan Islam mengajarkan untuk selalu mendahulukan perintah Allah dan menjauhkan diri dari larangan-Nya".

Sesuai dengan hadits Rasulullah saw sebagi berikut :

1] Jurnal ini merupakan bagian dari skripsi dari Yesika Novita L.G., NIM: 04121143375, yang diuji pada tanggal 13 Juni 2016 
An-Nu'man bin Basyri r.a menyatakan bahwa ia mendengar Rasulullah SAW bersabda (an-Nu'man mendekatkan dua jarinya kedua telinganya)

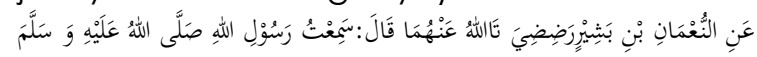

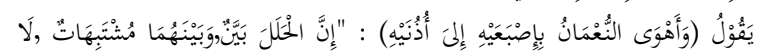

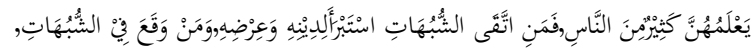

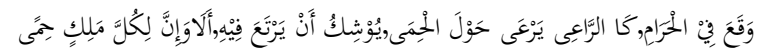

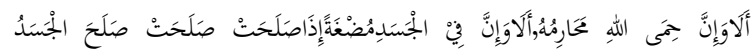

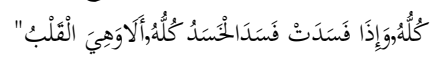

'ani'n-nu'mānibni basyirin raḍidiya ta'llāhu 'anhumā qāla: sami'tu rasuli'l-lāhi salla 'Illahu 'alaihi wasallama yaqūlu (wa ahwa'n-nu'mānu bi-ișba'aihi ila użunaihi) : "innalhalala bayyanun, wabainahumā musytabihatun, lā ya'lamuhunna kasirun 'mina'n-nāsi, famani't-taqā'sy-syubuhatistabra

alidinihi wa'irdihi, waman waka'a fi'sysyubuhāti, waqa'a filharāmi, ka'r-rā'i yar'a haula 'Ihima, yusiku an yarta'a fihi, 'ala wainna likulla maliki himan alā wainna hima'l-lāi mahārimuhu, alā wa inna filjasadi mudgatan iża șalahat șalahaljasadu kulluhu, wa iża fasadat fasada 'Ikhasadu kulluhu, alā wahiyalqalbu"

Artinya: An-Nu'man bin Basyri r.a menyatakan bahwa ia mendengar Rasulullah saw bersabda (an-Nu'man mendekatkan dua jarinya kedua telinganya) "Sesungguhnya yang halal telah nyata (jelas) dan yang haram telah nyata. Antara keduanya terdapat perkara yang diragukan yang tidak diketahui kebanyakan orang. Maka, siapa yang menjaga dirinya untuk tidak mengerjakan perkara yang diragukan , selamatlah agama dan pribadinya. Tetapi siapa yang jatun kedalam syubhat, berarti ia jatuh kedalam yang haram, tak ubahnya seperti gembala yang mengembala ditepi tanah larangan, khawatir ia jatuh kedalam. Ketahuilah, setiap kerajaan itu memiliki larangan dan larangan Allah ialah segala yang diharam-Nya. Ketahuilah, didalam tubuh manusia terdapat segumpal darah, jika baik gumpalan itu, baik pula keseluruhan. Tetapi jika rusak gumpalan itu, rusak pulalah tubuh seluruhnya. Ketahuilah gumpalan itu ialah hati" (H.R. Muslim nomor 956 dalam Al-Albani, 2005:453)
Banyak investor yang melihat NAB sebagai acuan dalam berinvestasi dan memperkirakan return yang diperolehDana Tabarru' dengan Dana Ujrah berbeda perlakuannya.

Ada beberapa faktor yang mempengaruhi Nilai Aktiva Bersih (NAB) reksadana saham syariah sehingga diharapkan dapat dijadikan indikator bagi investor. Faktor-faktor yang diduga memiliki pengaruh terhadap Nilai Aktiva Bersih (NAB) reksadana saham syariah adalah $\mathrm{BI}$ Rate dan risikounsystematicpasar.

Suku bunga adalah biaya untuk meminjam vang dan diukur dalam dolar per tahun untuk setiap satu dolar yang dipinjamnya (Samuelson dan Nordhaus, 2004:197). Jika diterapakan dalam kondisi Indonesia maka suku bunga merupakan jasa peminjaman vang dari bank kepada nasabah. Di indonesia suku bunga disebut BI Rate. BI Rate adalah suku bunga kebijakan yang mencerminkan sikap kebijakan moneter yang ditetapkan oleh bank Indonesia dan diumumkan kepada publik $(\mathrm{Bl}, 2016)$. Jika BI Rate dinaikkan, yang akan terjadi adalah investor akan memilih alternatif investasi yang memberikan pendapatan yang lebih tinggi. Akibatnya instrumen -instrumen pasar modal seperti saham tidak diminati bahkan dijual dan beralih keperbankan. Hal tersebut menyebabkan harga saham menurun sehingga keuntungan reksadana saham juga mengalami penurunan.

$$
\text { Faktor yang kedua diduga }
$$

mempengaruhi NAB adalah risiko unsystematic pasar. Risiko unsystematic 
pasar terjadi dipengaruhi oleh nilai sekuritas di pasar efek yang berfluktuasi sesuai dengan kondisi ekonomi secara umum. Mengingat kenyataan bahwa portofolio terdiri atas efek-efek dari pasar saham, maka terjadi fluktuasi di pasar efek berpengaruh langsung pada Nilai Aktiva Bersih reksadana. NAB menurun hal ini berarti return yang diperoleh sebagai salah satu indikator investasi juga menurun. Return dan risiko bergerak searah (Tandelilin, 2010:10).Reksadana memiliki indeks yang tercermin dalam indeks harga saham. Indeks harga saham adalah suatu indikator yang menunjukkan pergerakan harga saham untuk mengukur kinerja saham-saham suatu perusahaan. Indeks harga saham juga disebut sebagai indeks pasar saham karena merupakan indikator yang mengambarkan pergerakan hargaharga saham (Tendedilin, 2010:86). Seperti yang telah dijelaskan diatas untuk menilai kinerja reksadana mengunakan data NAB dan diperlukan acuan seperti reksadana konvensional yang mengacu pada kinerja IHSG (Indeks Harga Saham Gabungan). Cara pengukurannya dengan data historis melalui NAB, yaitu membandingkan selisih return reksadana saham dengan IHSG. Sedangkan acuan untuk reksadana syariah adalah ISSI (Indeks saham syariah),yaitu indeks saham yang mencerminkan keseluruhan saham syariah yang tercatat di BEl. suku bungan dan risikounsystematic pasar terhadap NAB merupakan kodisi yang bisa terjadi secara bersamaan dipasar modal.Tujuan Penelitian ini adalah Untuk menganalisis faktor-faktor yang

mempengaruhi Nilai Aktiva Bersih
Reksadana Manulife Syariah Sektor
Amanah.

II. LANDASAN PUSTAKA

Tabel 1.

Perbedaan Reksadana Syariah dan Konvensional

\begin{tabular}{|l|l|l|l|}
\hline $\begin{array}{l}\text { Jenis } \\
\text { reksadana }\end{array}$ & $\begin{array}{l}\text { Alokasi } \\
\text { investasi } \\
\text { dari dana } \\
\text { yang } \\
\text { terkumpul }\end{array}$ & $\begin{array}{l}\text { Potensi } \\
\text { hasil } \\
\text { dan } \\
\text { risiko } \\
\text { investasi }\end{array}$ & $\begin{array}{l}\text { Jangka } \\
\text { waktu yang } \\
\text { disarankan }\end{array}$ \\
\hline $\begin{array}{l}\text { Pasar } \\
\text { uang }\end{array}$ & $\begin{array}{l}\text { 100 } \\
\text { persen } \\
\text { efek } \\
\text { pasar } \\
\text { uang }\end{array}$ & Rendah & $\begin{array}{l}\text { Jangka } \\
\text { pendek <1 } \\
\text { tahun }\end{array}$ \\
\hline $\begin{array}{l}\text { Pendapat } \\
\text { an tetap }\end{array}$ & $\begin{array}{l}\text { Minimal } \\
80 \text { persen } \\
\text { efek } \\
\text { hutang }\end{array}$ & sedang & $\begin{array}{l}\text { Jangka } \\
\text { menengah } \\
\text { 1-3 tahun }\end{array}$ \\
\hline $\begin{array}{l}\text { Campura } \\
\mathrm{n}\end{array}$ & $\begin{array}{l}\text { Kombinasi } \\
\text { efek } \\
\text { hutang } \\
\text { dan } \\
\text { saham }\end{array}$ & Sedang & $\begin{array}{l}\text { Menenggah- } \\
\text { panjang }\end{array}$ \\
\hline saham & $\begin{array}{l}\text { Minimal } \\
80 \text { persen } \\
\text { saham }\end{array}$ & Tinggi & $\begin{array}{l}\text { Jangka } \\
\text { panjang, > 3 } \\
\text { tahun }\end{array}$ \\
\hline
\end{tabular}

Sumber : Pratomo (2007:34) Data telah diolah

Menurut Rahardjo (2004:71), Nilai Aktiva Bersih (NAB) per unit penyertaan merupakan jumlah $N A B$ dibagi dengan nilai jumlah unit Penyertaan yang beredar (outstanding) yang telah beredar (dimiliki investor) pada saat tertentu. Nilai Aktiva Bersih per unit diperhitungkan setiap hari oleh bank kunstodian setelah mendapat dana dari Manajer Investasi dan nialinya dapat dilihat dari surat kabar yang dilihat reksadana bersangkutan setiap hari. Besarnya NAB bisa berfluktuasi setiap hari, tergantung dari perubahan nilai efek dari portofolio. Meningkatnya NAB 
mengindikasikan naiknya nilai investasi pemegang saham / unit penyertaan. Begitu juga sebaliknya, menurunnya $N A B$ berarti berkurangnya nilai investasi pemegang unit penyertaan. Jadi NAB merupakan salah satu tolak ukur dalam memantau hasil dari suatu reksadana.

$\mathrm{Bl}$ Rate adalah suku bunga kebijakan yang mencerminkan sikap kebijakan moneter yang ditetapkan oleh bank Indonesia dan diumumkan kepada publik. Menurut Karl dan Fair (2001:52), suku bunga adalah pembayaran bunga tahunan. Dari suatu pinjaman, dalam bentuk persentase dari pinjaman yang diperoleh dari jumlah bunga yang diterima tiap tahun dibagi dengan jumlah pinjaman.

Risikounsystematic pasar adalah situasi ketika harga instrumen investasi mengalami penurunan yang disebabkan oleh menurunnya kinerja pasar saham atau pasar obligas. Istilah lainnya adalah pasar sedang mengalami kondisi bearish, yaitu harga-harga saham atau instrume investasi lainnya mengalami penurunan harga. Risiko unsystematic pasar yang terjadi secara tidak langsung akan mengakibatkan NAB (Nilai Aktiva Bersih) per Unit Penyertaan (UP) Reksadana akan mengalami penurunan juga. Oleh karena itu, apabila ingin membeli jenis Reksadana tertentu, Investor harus bisa memperhatikan trend pasar dari instrumen portofolio Reksadana itu sendiri.

Risikounsystematic pasar dalam penelitian ini adalah Variasi data penutupan Indeks Saham Syariah (ISSI) harian dalam satu bulan yang diukur menggunakan standar deviasi sejak Mei 2011 - Desember 2014. Risiko unsystematic pasar diukur dengan menggunakan standar deviasi dari naik turunnya nilai return dengan bulanan. Berikut Rumus standar deviasi menurut Hadi (2013:32)

$\sigma=$

$\sqrt{\frac{\sum_{i=1}^{n}(X-\overline{\mathrm{X}})^{2}}{n-1}}$

Keterangan:

$\sigma=$ Standart deviasi

$\mathrm{x}=$ Return pasar

$\overline{\mathrm{X}}=$ Rata-rata retrun pasar

$\mathrm{n}=$ Jumlah observasi

Berdasarkan latar belakang, rumusan masalah, tujuan dan manfaat penelitian, dan landasan teori di atas, maka ada tiga hipotesis pada penelitian ini, antara lain sebagai berikut:

$\mathrm{HI}$ :SUku Bunga dan risikounsystematic pasar berpengaruh terhadap Nilai Aktiva Bersih (NAB) Reksadana Manulife Syariah Sektor Amanah secara simultan signifikan

H2: Suku Bunga berpengaruh terhadap Nilai Aktiva Bersih (NAB) Reksadana Manulife Syariah Sektor Amanah secara parsial signifikan

H3 : risikounsystematic pasar berpengaruh terhadap Nilai Aktiva Bersih (NAB) Reksadana Manulife Syariah Sektor Amanah secara parsial signifikan

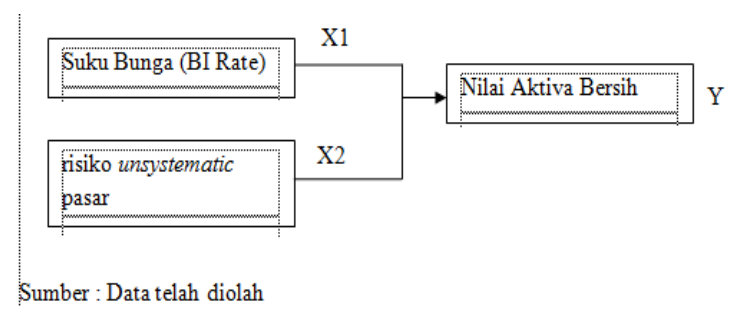


Gambar 1.

Model Analisis

\section{METODOLOGI PENELITIAN}

\section{Pendekatan Penelitian}

Pendekatan yang dilakukan dalam penilitian ilmiah ini adalah pendekatan kuantitatif. Penelitian ini menitik beratkan pada pengujian hipotesis, data yang digunakan harus terukur, dan akan menghasilkan kesimpulan yang dapat digeneralisasikan (Sugiyono, 1997: 10). Pendekatan ini lebih sering berupaya mengukur suatu konsep variabel, sehingga lebih mudah dipahami secara statistik. Menurut Arikunto dalam Anshori dan Iswati (2009:15) penelitian kuantitatif diharuskan menggunakan angka mulai dari pengumpulan data, penafsiran data, serta penampilan hasil penelitiannya oleh karena itu peneliti dituntut memahami dan menguasai statistik sebagai alat analisis data.

Berdasarkan latar belakang masalah, perumusan masalah dan tujuan penelitian, variabel-variabel yang akan diteliti dalam penelitian ini dapat diklasifikasikan atas dua kelompok variabel yaitu:

1. Variabel bebas (independent variable).

Variabel bebas atau (X) dalam penelitian ini adalah suku bunga $\left(X_{1}\right)$,risikounsystematic pasar $\left(X_{2}\right)$.

2. Variabel Terikat (dependent variable). Variabel terikat atau

dalampenelitian ini adalahNilai Aktiva Bersih

per unit yang selanjutnya disebut (NAB) (Y).
Berdasarkan

variabelvariabelyang digunakan, maka hubungan antarvariabel dapat dinyatakan dalam fungsisebagai berikut:

$Y=f(X 1, X 2)$

Bentuk persamaan regresi dapat

dirumuskan sebagai berikut :

$Y=a+\beta 1 X 1+\beta 2 X 2+$

e.......

Keterangan:

Y $=$ Variabel dependen (nilai aktiva bersih reksadana saham syariah)

$a=$ Konstanta

$\beta 1,2=$ Koefisien regresi masingmasingvariabel independen

$\mathrm{X} 1=$ Variabel independen 1 (suku bunga)

$\mathrm{X} 2=$ Variabel independen 2 (risikounsystematic pasar)

$\mathrm{e} \quad=$ Error dalam persamaan regresi

Tabel 2.

Definisi Operasional Variabel

\begin{tabular}{|c|c|c|c|}
\hline Variabel & Simbol & $\begin{array}{l}\text { Pengukur } \\
\text { an }\end{array}$ & Pengertian \\
\hline $\begin{array}{l}\text { Nilai } \\
\text { Aktiva } \\
\text { Bersih }\end{array}$ & $Y$ & $\begin{array}{l}\text { Rata- } \\
\text { rata } \\
\text { NAB/ Unit } \\
\text { bulanan }\end{array}$ & $\begin{array}{l}\text { Nilai Aktiva } \\
\text { Bersih } \\
\text { dalam } \\
\text { penelitian ini } \\
\text { adalah Nilai } \\
\text { Aktiva Bersih } \\
\text { per unit } \\
\text { yang } \\
\text { dihitung dari } \\
\text { total Nilai } \\
\text { Aktiva bersih } \\
\text { dibagi unit } \\
\text { penyertaan, } \\
\text { merupakan } \\
\text { data harian } \\
\text { yang } \\
\text { dikeluarkan } \\
\text { Oleh } \\
\text { Reksadana } \\
\text { Manulife } \\
\text { Syariah }\end{array}$ \\
\hline
\end{tabular}




\begin{tabular}{|c|c|c|c|}
\hline & & & $\begin{array}{l}\text { Sektor } \\
\text { Amanah } \\
\text { sejak Mei } \\
2011 \text { sampai } \\
\text { dengan } \\
\text { Desember } \\
2014 \text { dalam } \\
\text { satuan } \\
\text { rupiah dan } \\
\text { diakses } \\
\text { melalui } \\
\text { (pusatdata. } \\
\text { kontan.co.id } \\
\text { l }\end{array}$ \\
\hline $\begin{array}{l}\text { Suku } \\
\text { Bunga }\end{array}$ & $\mathrm{X} 1$ & $\begin{array}{l}\text { Bl Rate } \\
\text { bulanan }\end{array}$ & $\begin{array}{l}\text { Bl Rate } \\
\text { adalah suku } \\
\text { bunga } \\
\text { kebijakan } \\
\text { yang } \\
\text { mencermink } \\
\text { an sikap } \\
\text { kebijakan } \\
\text { moneter } \\
\text { yang } \\
\text { ditetapkan } \\
\text { oleh bank } \\
\text { Indonesia } \\
\text { setiap bulan } \\
\text { dan } \\
\text { diumumkan } \\
\text { kepada } \\
\text { publik. }\end{array}$ \\
\hline $\begin{array}{l}\text { risikounsy } \\
\text { stematic } \\
\text { pasar }\end{array}$ & $\mathrm{X} 2$ & $\begin{array}{l}\text { Standart } \\
\text { devisi } \\
\text { bulanan } \\
\text { dari data } \\
\text { ISSI } \\
\text { harian. }\end{array}$ & $\begin{array}{l}\text { risikounsyste } \\
\text { matic } \\
\text { pasardalam } \\
\text { penelitian ini } \\
\text { adalah } \\
\text { Variasi data } \\
\text { penutupan } \\
\text { Indeks } \\
\text { Saham } \\
\text { Syariah (ISSI) } \\
\text { harian } \\
\text { dalam satu } \\
\text { bulan yang } \\
\text { diukur } \\
\text { menggunak } \\
\text { an standar } \\
\text { deviasi sejak } \\
\text { Mei } 2011 \text { - } \\
\text { Desember } \\
2014 \\
\text { dengan } \\
\text { Rumus (2.1) } \\
\text { pada bab 2. }\end{array}$ \\
\hline
\end{tabular}

Sumber : data telah diolah

\section{Jenis dan Sumber Data}

Pada penelitian kali ini data yang digunakan adalah data sekunder. Data sekunder yang digunakan pada penelitian ini antara lain Nilai Aktiva Bersih harian Reksadana Manulife Syariah Sektor Amanah Mei 2011 sampai dengan Desember 2014 data tersedia di website (pusatdata.kontan.co.id). Data Bi rate diambil dari website resmi Bank Indonesia yang dipublish Bank Indonesia dengan data bulanan Mei 2011 sampai dengan Desember 2014. Data risikounsystematic pasarmengunakan acuan pada Indeks Harga Saham Syariah yaitu Indeks Saham Syariah Indonesia (ISSI) yang tersedia di yahoo finance dengan data harian Mei 2011 sampai dengan Desember 2014.

\section{Kriteria Populasi dan Sampel}

\section{Populasi}

Populasi adalah wilayah generalisasi yang terdiri atas: obyek/subyek yang mempunyai kualitas dan karakteristik tertentu yang ditetapkan oleh peneliti untuk dipelajari dan kemudian ditarik kesimpulannya (Sugiyono, 2005:80).

\section{Sampel}

Sampel adalah bagian dari jumlah dan karakteristik yang dimiliki oleh populasi, (Anshori dan Iswati, 2009:94). Sampel dalam penelitian ini mengunakan sampel jenuh, sampel jenuh adalah teknik penentuan sampel bila anggota populasi digunakan sebagai sampel, (Sugiyono, 2005:6). Sampel dalam penelitian ini adalah sama dengan populasinya yaitu 
Nilai Aktiva Bersih Reksadana Saham Manulife Syariah Sektor Amanah. Sehingga Nilai Aktiva Bersih reksadana saham syariah yang diambil 44 bulan terakhir tiap variabel dengan periode Mei 2011 hingga Desember 2014, sehingga totalnya 44 sampel.

\section{Teknik Analisis}

\section{Statistik Deskriptif}

Analisis statistik deskriptif digunakan untuk mendapatkan gambaran umum sampel penelitian meliputi mean, nilai maksimum, nilai minimum, varian, dan standar deviasi dari setiap variabel dalam model. Hasil analisis akan ditampilkan dalam bentuk tabel.

Tabel 3.

Statistik Deskriptif

\begin{tabular}{|l|r|r|r|r|r|}
\hline & $\mathrm{N}$ & $\begin{array}{r}\text { Mini } \\
\text { mu } \\
\mathrm{m}\end{array}$ & $\begin{array}{c}\text { Maxim } \\
\text { um }\end{array}$ & Mean & $\begin{array}{c}\text { Std. } \\
\text { Devia } \\
\text { tion }\end{array}$ \\
\hline NAB & 44 & $\begin{array}{r}255 \\
1.13 \\
24\end{array}$ & $\begin{array}{r}3844.6 \\
115\end{array}$ & $\begin{array}{r}3248.09 \\
61\end{array}$ & $\begin{array}{r}363.7 \\
631\end{array}$ \\
\hline $\begin{array}{l}\text { BI_RA } \\
\text { TE }\end{array}$ & 44 & $\begin{array}{r}0.05 \\
75\end{array}$ & 0.0750 & 0.0655 & $\begin{array}{r}0.007 \\
5\end{array}$ \\
\hline $\begin{array}{l}\text { risikou } \\
\text { nsyste } \\
\text { matic } \\
\text { pasar }\end{array}$ & 44 & $\begin{array}{r}0.00 \\
00\end{array}$ & 8.3837 & 2.4354 & $\begin{array}{r}1.639 \\
2\end{array}$ \\
\hline
\end{tabular}

Sumber: data diolah

\section{Pengujian Penyimpangan Asumsi Klasik}

Uji penyimpangan asumsi klasik dilakukan untuk mengetahui beberapa penyimpangan yang terjadi pada data yang digunakan untuk penelitian. Hal ini agar model regresi bersifat BLUE (Best Linear Unbiased Estimated). Asumsi klasik yang digunakan pada penelitian ini yaitu: uji normalitas, multikolinearitas, heteroskedastisitas dan autokorelasi.
Kriteria statistik model digunakan untuk melihat seberapa baik model atau variabel yang digunakan dalam suatu penelitian. Criteria statistik model yang digunakan dalam penelitian ini meliputi Koefisien determinasi, Analisis Regresi Berganda, Uji Signifikan Simultan (Uji F), Uji Signifikan Parsial (Uji T).

\section{IV.Hasil dan Pembahasan}

\section{Deskripsi Hasil Penelitian}

Analisis statistik deskriptif digunakan untuk mengetahui deskripsi suatu data yang dilihat dari nilaiminimum, maximum, mean,standart deviation dan jumlah observasi.

Tabel 4.

Hasil Uji Asumsi Klasik

\begin{tabular}{|c|c|c|c|c|}
\hline NO. & $\begin{array}{c}\text { UJI } \\
\text { ASUMSI } \\
\text { KLASIK }\end{array}$ & JENIS & HASIL & KEPUTUSAN \\
\hline 1 & $\begin{array}{l}\text { Uji } \\
\text { Norm } \\
\text { ali- } \\
\text { tas }\end{array}$ & $\begin{array}{l}\text { grafik } \\
\text { histogr } \\
\text { am } \\
\text { maupu } \\
\text { n } \\
\text { grafik } \\
\text { P-P plo }\end{array}$ & $\begin{array}{l}\text { Membentu } \\
\text { k lonceng } \\
\text { dan } \\
\text { penyebara } \\
\text { n data (titik) } \\
\text { pada } \\
\text { sumbu } \\
\text { diagonal } \\
\text { dari grafik } \\
\text { melalui } \\
\text { grafik } \\
\text { Normal } \\
\text { Probability } \\
\text { Plot (NPP). }\end{array}$ & $\begin{array}{l}\text { Data } \\
\text { terdistrib } \\
\text { usi } \\
\text { normal }\end{array}$ \\
\hline 2 & $\begin{array}{l}\text { Uji } \\
\text { Auto } \\
\text { ko- } \\
\text { relasi }\end{array}$ & $\begin{array}{l}\text { Durbin- } \\
\text { Watso } \\
\mathrm{n}(\mathrm{DW}- \\
\text { test) }\end{array}$ & 0.151 & $\begin{array}{l}\text { tidak } \\
\text { ada } \\
\text { kesimpul } \\
\text { an }\end{array}$ \\
\hline 3 & $\begin{array}{l}\text { Uji } \\
\text { Heter } \\
\text { oske } \\
\text { dasti- } \\
\text { sitas }\end{array}$ & $\begin{array}{l}\text { Scatter } \\
\text { plot }\end{array}$ & $\begin{array}{l}\text { titik - titik } \\
\text { menyebar } \\
\text { dan tidak } \\
\text { membentu } \\
\text { k pola }\end{array}$ & $\begin{array}{l}\text { Memen } \\
\text { uhi uji } \\
\text { heterosk } \\
\text { edastisit } \\
\text { as. }\end{array}$ \\
\hline
\end{tabular}

\section{KriteriaStatistik Model}




\begin{tabular}{|c|c|c|c|c|}
\hline 4 & $\begin{array}{l}\text { Uji } \\
\text { Multi } \\
\text { kolin } \\
\text { earit } \\
\text { a-s }\end{array}$ & $\begin{array}{l}\text { Varian } \\
\text { ce } \\
\text { Inflatio } \\
n \\
\text { Factor } \\
\text { (VIF) }\end{array}$ & $\begin{array}{l}1.001 \& \\
1.001\end{array}$ & $\begin{array}{l}\text { Bebas } \\
\text { Multikoli } \\
\text { nearitas }\end{array}$ \\
\hline
\end{tabular}

Sumber : Data diolah

\section{HASIL PEMBAHASAN}

Persamaan untuk regresi linier berganda dalam penelitian ini dapat ditulis sebagai berikut:

$$
\begin{gathered}
Y=a+\beta 1 \text { Suku Bunga }+\beta 2 \text { Risiko } \\
\text { unsystematic pasar }+e \\
Y=2036.004+19633.624 \text { Suku Bunga - } \\
\text { 30.439risiko unsystematic pasar }
\end{gathered}
$$

Uji F

Hasil penelitian menyatakan besarnya nilai F-hitung berdasarkan besarnya nilai a sebesar 5\% yaitu 4.549 dengan tingkat signifikan 0.016. Nilai signifikansi ini lebih kecil dari 0,05 sehingga dapat disimpulkan bahwa variabel SukU Bunga $\left(X_{1}\right)$, risikounsystematic pasar $\left(X_{2}\right)$, secara bersama-sama berpengaruh terhadap Nilai Aktiva Bersih Reksadana Syariah secara signifikan. Setelah dilakukan pengujian dengan menggunakan uji $F$ maka langkah selanjutnya melakukan pengujian dengan uji t, karena apabila ada pengaruh secara bersama - sama maka sekurang - kurangnya ada 1 variabel yang berpengaruh parsial.

Hasil penelitian menunjukkan pengaruh suku bunga dan risiko unsystematic pasar terhadap NAB secara simultan signifikan. Hal ini sesuai dengan dugaan peneliti dalam hipotesis, Yang berarti menerima $\mathrm{H}_{1}$ dan menolak $\mathrm{H}_{\mathrm{o}}$.Hasil penelitian ini membuktikan bahwa terdapat pengaruh Suku Bunga dan Risiko unsystematic pasar terhadap Nilai Aktiva Bersih (NAB) secara simultan signifikan. Hubungan antara suku bungan dan risiko unsystematic pasar terhadap NAB merupakan kodisi yang bisa terjadi secara bersamaan dipasar modal. Menurut Dornbusch dan Fischer (1994:86), terdapat keseimbangan dalam faktor makro ekonomi pasar aset hingga dapat dilihat hubungan antar variabel makroekonomi (suku bunga, inflasi, dll) dengan NAB reksadana. Sehingga suku bunga selalu dijadikan acuan untuk mempertimbangkan risk dan return oleh investor dalam berinvestasi. Kenaikan suku bunga akan menyebabkan biaya investasi meningkat dan jumalah pengeluaran investasi akan menurun, akibat selanjutnya adalah berpengaruh terhadap nilai investasi yang akan dibagikan kepada investor.

Kondisi yang terjadi di pasar modal juga mengikuti kondisi perekonomian yang ada, pada kondisi perekonomian yang tidak kondusif maka memungkinkan terjadinya risiko unsystematic pasar yang cukup tinggi dan suku bunga yang juga akan bergerak. Pada saat suku bunga dan risiko unsystematic pasar yang meningkat karena perekonomian yang tidak kondusif dapat terjadi dalam satu periode atau dalam suatu waktu, keduanya kemudian bisa berdampak pada Nilai Aktiva Bersih reksadana secara bersama-sama sehingga hipotesis pada penelitian ini adalah ada pengaruh secara bersama- sama suku bunga dan risiko unsystematic pasar terhadap NAB terbuktibenar.Dalam islam dikatakan 
bahwa tidak ada yang mengetahui secara pasti apa yang akan terjadi di hari esok, termasuk yang terjadi pada suku bunga dan risiko unsystematic pasar dalam investasi, sesuai dengan Al-Quran surat AlHasyr ayat 18 sebagai berikut :

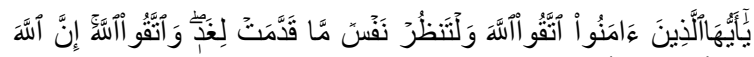

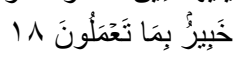

Yā ayyuhallazina āmanuttaqu'l-lāha wal tanzur nafsun mā qad damat ligad(ligadin), wattaku'l-lāh(wattaku'llāha), inna'l-lāha khabirun bi mā ta'malūn(ta'malūna).

Artinya: "Hai orang-orang yang beriman, bertakwalah kepada Allah dan hendaklah Setiap diri memperhatikan apa yang telah diperbuatnya untuk hari esok (akhirat); dan bertakwalah kepada Allah, Sesungguhnya Allah Maha mengetahui apa yang kamu kerjakan" (QS. Al-Hasyr 59:18, Kementrian Agama Republik Indonesia, 2015:548)

\section{Uji T}

Nilai uji † variabel Suku Bunga adalah sebesar 2.886 dengan tingkat signifikansi 0,006 . Nilai signifikansi uji t ini lebih kecil dari 0,05 . Oleh karena signifikansi dibawah 0,05 maka dapat disimpulkan bahwa Suku Bungaberpengaruh signifikan terhadap Nilai Aktiva Bersih Reksadana Syariah, sehingga Ho ditolak.

Hasil penelitian menunjukkan pengaruh suku bunga terhadap NAB secara parsial signifikan. Hal ini sesuai dengan dugaan peneliti dalam hipotesis, Yang berarti menerima $\mathrm{H}_{1}$ dan menolak Ho.Hasil penelitian ini membuktikan bahwa terdapat pengaruh Suku Bunga dan Risiko unsystematic pasar terhadap Nilai Aktiva Bersih (NAB)secara parsial signifikan. Suku bunga menjadi bagian penting dalam berinvestasi. MenurutTeori Klasik, Investasi merupakan fungsi tingkat suku bunga. Semakin tinggi tingkat bunga, semakin kecil keinginan masyarakat untuk mengadakan investasi. Karena keuntungan yang diharapkan dari investasi tersebut akan lebih dari tingkat bunga (biaya penggunaan pinjaman tersebut). Penelitian ini sesuai dengan hasil penelitian yang dilakukan oleh Nurlaili (2012), bahwa perubahan suku bunga $\mathrm{Bl}$ dapat mempengaruhi variablitas dari return suatu investasi. Hasil penelitian yang dilakukan Nurlaili, menunjukkan bahwa BI Rate berpengaruh secara signifikan terhadap nilai aktiva bersih reksadana saham.

Nilai uji $\dagger$ variabel Risiko unsystematic pasar adalah sebesar $-0,970$ dengan tingkat signifikansi 0,338. Nilai signifikansi uji $\dagger$ ini lebih besar dari 0,05. Oleh karena signifikansi diatas 0,05 maka dapat disimpulkan bahwa Risiko unsystematic pasar berpengaruh tidak signifikan terhadap Nilai Aktiva Bersih Reksadana Syariah, sehingga Ho diterima.

Hasil penelitian menunjukkan pengaruh Risiko unsystematic pasar terhadap NAB secara parsial tidak signifikan. Hal ini tidak sesuai dengan dugaan peneliti dalam hipotesis, yang berarti menerimaHo dan menolakH $H_{1}$. Hasil penelitian ini membuktikan bahwa pengaruh Suku Bunga dan Risiko unsystematic pasar terhadap Nilai Aktiva Bersih (NAB) secara parsial tidak signifikan. Hal ini menunjukkan bahwa fluktuasi harga saham dipasar saham mempengaruhi NAB reksadana berjenis saham tetapi tidak 
signifikan, hal ini terjadi karena fluktuasi tiap saham di pasar saham akan berbedabeda sehingga masing-masing saham memiliki tingkat sensitifitas yang berbedabeda pula terhadap setiap perubahan yang terjadi dipasar saham. Menurut Tandelilin (2010:10) risiko memiliki hubungan searah dengan return. Namun hasil penelitian ini menunjukkanhasil yang tidak signifikan hal ini dapat terjadi karena ketika investor menamkan investasi pada reksadana, investor sudah bisa mengukur tingkat risiko yang akan dihadapi. Pasar modal pada kondisi tertentu tidak akanmenghasilkan return konstan pasti akan ada pergerakan atau berfluktuasi baik karena kondisi ekonomi atau dari internal perusahaan itu. Kesadaran akan pergerakan yang terjadi di risiko unsystematic pasar sudah tidak menjadi kekhawatiran bagi investor untuk menanamkan modalnya di RDS, meskipun reksadana dalam penelitian ini merupakan reksadana berjenis saham, namun jumlah modal dalam investasi pada reksadana tergolong kecil seperti yang dijelaskan pada manfaat reksadana hanya dengan vang 100.000,- kita sudah dapat berinvestasi di reksadana, kalaupun investor mengalami kerugian akibat risiko unsystematic pasar yang berfluktuatif, hal itu tidak terlalu merugikan jika dibandingkanm dengan investor yang meananamkan modalnya di pasar modal dengan membeli saham yang cukup besar sehingga memerlukan modal yang besar pula, bila di rds modal tidak terlalu besar.

\section{Simpulan}

1. Pengaruh suku bunga dan risiko unsystematic pasar terhadap Nilai Aktiva Bersih (NAB) secara simultan signifikan, dengan signifikan sebesar 0,016 .

2. Pengaruh suku bunga terhadap Nilai Aktiva Bersih (NAB) secara parsial signifikan, dengan signifikan sebesar 0,006 .

3. Pengaruh risiko unsystematic pasar terhadap Nilai Aktiva Bersih (NAB) secara parsial tidak signifikan, tingkat signifikan sebesar 0,338.

\section{DAFTAR PUSTAKA}

Al Albani, M Nashiruddin. 2005. Ringkasan Shahih Muslim. Jakarta: Gema Insani

Anshori, Muslich dan Iswati, Sri. 2009. Buku Ajar Metode Penelitian Kuantitatif. Edisi Pertama. Surabaya: Airlangga University Pers

Dornbusch, Rudiger dan Stanley Fischer. 1994. Makroekonomi. Edisi keempat. Penerbit Erlangga. Jakarta.

Fatwa DSN-MUI. 2001. Fatwa Dewan Syariah Nasional No. 20/DSN-MUI/IX/2001 tentang Reksadana Syari'ah

Hadi, Nor.2013. Pasar Modal Acuan Teoretis dan Praktis Investasi di Instrumen Keungan Pasar Modal. Yogyakarta : Graha IImu

Karl, E Case dan Fair, C Rai. 2001. Prinsip Prinsip Ekonomi Makro. Jakarta : Prenhalindo

Kementrian Agama Republik Indonesia. 2015. Al-Qur'an dan Terjemahannya. Solo: PT Tiga Serangkai Pustaka Mandiri

Nurlaili, Nunuk. 2012. Pengaruh IHSG dan rate Bank Indonesia Terhadap NAB Reksadana Saham Syariah, Tesis MM. Universitas : Terbuka Indonesia

Pratomo, Eko P. 2007. Berwisata ke Dunia Reksa Dana. Jakarta: Gramedia Pustaka Utama.

Raharjo, Sapto. 2004. Panduan Investasi Reksadana Pilihan Bijak Berinvestasi dan Mengembangkan Dana. Jakarta:PT Alex Media Komputindo 
Ryandono, M Nafik. 2009. Bursa Efek dan Investasi Syariah. Jakarta :Serambi

Samuel, Paul A dan William D. Nordhaus. 2004. Ilmu Makro Ekonomi. Edisi ke tujuh belas. Jakarta : Gramedia

Sugiyono, 1997, Statistika Untuk Penelitian, Bandung: Alfabeta

Sugiyono, 2005, Memahami Penelitian Kualitatif, Bandung : Alfabeta

Tandelilin,Edarus.2010. Portofolio dan Investasi. Yogyakarta: Kanisius.

www.bi.go.id diakses tanggal 12Januari 2016 pukul 19.08 